\title{
New rules propose greater scrutiny for NIH grant recipients
}

Following a string of high-profile scandals, the US government is pushing for stricter oversight of grants given by the National Institutes of Health (NIH). The trend has many researchers worried that they might have to start accounting for their time and money or face being investigated.

Much of the scientists' concern centers on detailed new guidelines from the US Department of Health and Human Services (HHS), which oversees the NIH, but other auditing and investigative efforts could also cause trouble for some institutions. The guidelines dictate specifics on research oversight and might require scientists to track time spent on teaching, patient care or research. Meanwhile, Congress is also prodding the HHS to investigate graduate student stipends.

The Office of Inspector General, the HHS' enforcement arm, released the draft guidelines on 28 November and is soliciting comments until the end of January. Agency officials declined to comment on any aspect of the guidelines.

The rules are technically voluntary, but research advocates predict they will have the effect of laws. "You take these things quite seriously when they're issued by the inspector general," says Susan Ehringhaus, general counsel of regulatory affairs at the Association of American Medical Colleges, a research lobby group. "This is somebody that you pay attention to, because that's an office that will set up audits," she says.
The draft says that, in certain circumstances, the failure to accurately account for time and effort "could subject an institution to civil or criminal fraud investigations." An HHS official close to the issue, speaking on condition of anonymity, agreed that institutions that follow the guidelines would be likely to fare better in a fraud investigation or audit.

The government has already scrutinized several NIH grant recipients in the past few years, often leading to large out-of-court settlements (see table). Prompted by a Wall Street Journal report on the investigation of Cornell's Weill Medical College, also covered in Nature Medicine (11, 810; 2005), the US House of Representatives in October asked the HHS to step up its grant oversight. Audits may become more common in response to the new congressional pressure.

In their letters to the department, Republican Congressmen Joe Barton and Ed Whitfield called for both a general increase in audits and a specific investigation of graduate student stipends (Nature 437, 601; 2005). The HHS had cracked down on creative stipend accounting at several institutions in 1994, but the Congressmen contend that some universities may still be

\begin{tabular}{|c|c|c|c|}
\hline \multicolumn{4}{|c|}{ Settlements in Recent Investigations of NIH Grant Recipients. } \\
\hline Date & Institution & Claim & Settlement* \\
\hline $\begin{array}{l}\text { July } \\
2005\end{array}$ & $\begin{array}{l}\text { Cornell Weill } \\
\text { Medical } \\
\text { College }\end{array}$ & $\begin{array}{l}\text { Double-billing of NIH and } \\
\text { Medicaid, misappropria- } \\
\text { tion of research funds. }\end{array}$ & $\$ 4.4$ million \\
\hline $\begin{array}{l}\text { May } \\
2005\end{array}$ & Mayo Clinic & $\begin{array}{l}\text { Misappropriation of } \\
\text { research funds. }\end{array}$ & $\$ 6.5$ million \\
\hline $\begin{array}{l}\text { April } \\
2005\end{array}$ & $\begin{array}{l}\text { University of } \\
\text { Alabama }\end{array}$ & $\begin{array}{l}\text { Double-billing of NIH and } \\
\text { Medicare, overstatement } \\
\text { of research costs. }\end{array}$ & $\$ 3.4$ million \\
\hline $\begin{array}{l}\text { June } \\
2004\end{array}$ & $\begin{array}{l}\text { Harvard } \\
\text { University }\end{array}$ & $\begin{array}{l}\text { Misbilling of salaries and } \\
\text { expenses on grants. }\end{array}$ & $\$ 2.4$ million \\
\hline $\begin{array}{l}\text { February } \\
2004\end{array}$ & $\begin{array}{l}\text { Johns Hopkins } \\
\text { University }\end{array}$ & $\begin{array}{l}\text { Overstatement of faculty } \\
\text { time and effort spent on } \\
\text { sponsored research. }\end{array}$ & $\$ 2.6$ million \\
\hline $\begin{array}{l}\text { February } \\
2003\end{array}$ & $\begin{array}{l}\text { Northwestern } \\
\text { University }\end{array}$ & $\begin{array}{l}\text { Overstatement of faculty } \\
\text { time and effort spent on } \\
\text { sponsored research. }\end{array}$ & $\$ 5.5$ million \\
\hline
\end{tabular}

overbilling the NIH for graduate students' pay. The HHS official declined to discuss specific investigations, but said the agency is likely to comply with Congress' request.

At the NIH, officials declined to comment on any grant oversight issues except the new draft guidelines. In an official statement on the guidelines, Norka Ruiz Bravo, NIH deputy director for extramural research, said, "The $\mathrm{NIH}$ is pleased to see these principles issued as guidance for comment."

Alan Dove, New York

\section{Reshuffle at infectious}

For nearly three years, the US government has been reorganizing its Centers for Disease Control and Prevention (CDC) — and some employees are sick of it. The process is taking too long, they say, and the end result is unlikely to be an improvement.

CDC director Julie Gerberding first announced the reshuffle in June 2003, and Congress gave its final approval to the ongoing changes in April 2005. The plan aims to make the agency more efficient, innovative and responsive to changing circumstances.

The reorganization, cheerfully dubbed the 'futures initiative', does not have a set date for completion, but within the agency, it has already won many critics. An internal survey in April revealed that $65 \%$ of respondents were "not at all" or "a little" confident that the initiative would result in positive changes. The agency plans to take another survey next April.

"There is widespread, almost universal, dissatistfaction and demoralization at the CDC," says a senior public health researcher who is long-acquainted with the agency.
In the new structure, the CDC's 11 scientific divisions, which reported directly to the office of the director, now report to one of six "coordinating centers". These new centers are meant to allow for more research and collaboration between divisions. But critics in the agencynone of whom will speak on the record for fear of reprisals - say the centers have only added an unnecessary level of bureaucracy.

Some critics say new administrators, many of whom were appointed in November, are not experienced enough and were picked for their allegiance to Gerberding. "The reorganization is emasculating the [divisions] and putting in cronies," says a senior official. "It's just endless reorganization and reshuffling."

Unhappiness at the CDC mostly roils below the surface because the agency frowns on outspoken complaint. One manager who spoke openly about his unhappiness was reportedly disciplined for misconduct. "Raising honest concerns is not appreciated," says a senior official. "Anybody here who talks on the record is dead meat."
Off the record, the staff complain about increasing bureaucracy, bad management and meddling from the Bush administration. The last charge was exemplified by the smallpox vaccine initiative, which some $C D C$ scientists say was insufficiently grounded in science. An Institute of Medicine report in March 2005 found that national security interests superseded the science behind the program.

Donna Garland, chief of enterprise communications for the agency, admits that there has been some unhappiness among CDC staff, but says much of the irritation is misplaced. "A lot of concerns come from issues that predate the futures initiative," she says. "Change is constant. I think in the federal government we lose track of that sometimes."

Still, to improve morale, the agency has created a 'ton of feathers' task force, the idea being that little irritants—such as burdensome travel clearance procedures or long waits for computer support-may be small matters, but can collectively take a heavy toll.

Emma Marris, Washington DC 